\title{
Inferentialism in mathematics education: introduction to a special issue
}

\author{
Arthur Bakker $^{1}$ (D) Stephan Hußmann ${ }^{2}$
}

Received: 9 September 2017 / Accepted: 15 September 2017 /

Published online: 1 October 2017

(C) Mathematics Education Research Group of Australasia, Inc. 2017

\section{What is inferentialism?}

Inferentialism, as developed by the philosopher Robert Brandom (1994, 2000), is a theory of meaning. The theory has wide-ranging implications in various fields but this special issue concentrates on the use and content of concepts. The key idea, relevant to mathematics education research, is that the meaning of concepts is understood in terms of their role in reasoning practices. In line with the anti-representationalist literature in mathematics education (e.g., Cobb et al. 1992), Brandom explains the meaning of representations in terms of reasoning practices rather than the possibility of reasoning or making inferences on the basis of representations. This view does by no means diminish the significance of representations (signs, diagrams, graphs, symbols...). Rather, understanding how representations come to be is enriched by appreciating that they gain their meaning in human activities in which, as a matter of course, people exercise reason that relies on particular inferences.

Normativity is a key idea in inferentialism. Brandom suggests that "concepts are broadly inferential norms that implicitly govern practices of giving and asking for reasons" (Brandom 2009, p. 120). Inferentialism offers a holist rather than an atomistic view on concepts. Formal semantics has mainly been atomistic, explaining complex expressions in terms of independent simpler ones and we see a similar tendency in teaching (noted by Bakker and Derry 2011). Brandom writes:

Arthur Bakker

a.bakker4@uu.nl

Stephan Hußmann

stephan.hussmann@tu-dortmund.de

1 Freudenthal Institute, Utrecht University, Princetonplein 5, 3584 CC Utrecht, The Netherlands

2 Dortmunder Kompetenzzentrum für Lehrerbildung und Lehr-/Lernforschung, Technical University Dortmund, Emil-Figge-Str. 50, 44227 Dortmund, Germany 
By contrast, inferentialist semantics is resolutely holist. On an inferentialist account of conceptual content, one cannot have any concept unless one has many concepts. For the content of each concept is articulated by its inferential relations to other concepts. Concepts, then, must come in packages (though it does not yet follow that they must come in just one great big one). (Brandom 2000, p. 15-16; emphases original)

Brandom (2000) characterises inferentialism as pragmatist, expressivist, and rationalist. What people think or express is based on what they implicitly know how to do. We see a good fit with the view that "mathematical activity is human activity" (Lakatos 1976, p. 146; see also Freudenthal 1973). In our perspective, Brandom's rationalist language fits well with the inferential nature of mathematics.

\section{What inferentialism is not}

Inferentialism is not a learning theory or a pedagogical approach. Inferentialism is also silent on psychological issues. Yet we think the philosophical debates which may be connected with inferentialism (McDowell 1994/1996; Smith 2002; Weiss and Wanderer 2010) form an interesting resource with which to approach thorny old issues in mathematics education research with fresh eyes, in particular where it comes to epistemological topics such as concepts, knowledge, or reason.

It often takes many years before philosophical ideas trickle through to educational theory. The history of constructivism is an example of how philosophical ideas through trends in psychology came to influence educational research and practice. Where constructivism highlighted the need to take a student perspective on learning, cultural-historical theories stressed the importance of culture, history, and the social. Inferentialism - in our view - has the potential to highlight the importance of agency of the learners who participate in a social practice by giving and asking for reasons - and thus puts more emphasis on rationality. Reason is not restricted to the explicit and formalised type of inference that we know of statistical inference or mathematical deduction. Rather, Brandom's ideas can be extended to encompass the kinds of implicit and tacit inferences that are not immediately explicit or expressed in language: Saying is rooted in doing (Brandom 2008); knowing-that is based on knowing-how (Brandom 2000).

\section{Reason is not purely mental, cold, or disembodied}

Brandom's view on reason may at first sound contradictory to what is often concluded from psychological research. Tversky and Kahneman's (1981) experiments are renowned for showing how people's choices and decisions are often inconsistent and incoherent. One possible conclusion, regularly drawn in the literature, is that people are irrational, or at least far less rational than often thought (Erickson et al. 2013, Chapter 6). However, their experiments also show that people give reasons and feel obliged to give reasons for whatever choice or decision they make - even if they are contradictory from a logical perspective. Yes, one could use the term "irrational" for logically inconsistent reasoning, 
but in most cases, one could also call people rational in a more modest sense because they give and take reasons - even if these are inconsistent, incoherent, or incorrect from a particular perspective. Indeed, as is well appreciated, people do not always know the reasons informing why they do something, but what is interesting is the fact that we do offer reasons for our choices, even if post hoc (see Schindler and Hußmann 2013 for examples in mathematics education). Inferentialism brings this aspect of human reasoning with a small $r$ rather than a capital $R$ to the fore.

Such more modest or richer conception of reason treats humans as rational creatures but does not limit acting for reasons to an intellectualist form of justification, one in which reasons are overt. The philosopher Bernard Williams (1981) famously made a case against the conscious rational justification of moral acts by the actor. He used the phrase "one thought too many" to resist the idea that a moral principle could be the conscious basis of a person choosing to save his wife from drowning over another person. Rather, he emphasised the embodied nature of the act. The act is not the result of a rational computation and yet testifies to an embodied responsiveness to reason (see also Schear 2013).

Such examples also illustrate that reason need not to be purely mental or "cold," as emphasised by Mackrell and Pratt (2017) in their contribution on constructionism. Reason is interwoven with action and affect. Bakker et al. (2017) note that emotions can be reasons for action and action the reason for an emotion. Reasons are, in their view, relations between entities that can be analytically distinguished but that are in practice interwoven.

Such interpretations of inferentialism allow us to avoid common but unfortunate dichotomies (e.g., cognition and affect). One further problematic dichotomy is the one between mathematics and context. When mathematics is used in context, such as a workplace, multiple reasons are at stake, some of which may be mathematical or statistical but other perhaps more pragmatic or contextual (Bakker et al. 2008). For example, whether machine operators fitting windscreens in cars can deviate from statistically defined targets depends also on pragmatic issues: Are there no customer complaints? Then there is no need to invest a lot of time and effort to meet the guidelines from statistical process control. An inferentialist perspective using notions such as "webs of reasons" can help us analyse a diversity of reasons involved, some of which may be mathematical. An inferentialist lens can help us as researchers treat reasons democratically, that is without superimposing a predefined hierarchy on types of reasons. In some cases, such as the windscreen-fitting example, pragmatic and contextual reasons may supersede statistical ones, but in other cases, statistical considerations may help detect a practical problem that without data would not have easily come to light. Such real-life examples illustrate how mathematical, statistical, and other reasons are often interwoven in context. As Brandom (2009) writes, "I would prefer to understand the inferential commitment expansively, as including the circumstances and consequences it relates" (p. 121).

This inferentialist view not only resonates with situated views on cognition but also points to the close link between judgement and action. Judgement is theoretical, and action is practical activity. Concepts are not individual or mental entities. Rather,

The norms and rules that determine what we have committed ourselves to, what we have made ourselves responsible for, by making a judgment or performing an 
action, Kant calls 'concepts'. That is, the commitments embodied in judgments and actions are ones we may or may not be entitled to, so that the question of whether they are correct, whether they are commitments we ought to acknowledge and embrace, can always be raised (p. 115).

\section{Why introduce inferentialism in mathematics education?}

One challenge of mathematics education research is to understand how people learn concepts. In inferentialism, this process is understood in terms of reasoning arising within a social game of giving and asking for reasons. In line with the idea of sociomathematical norms that are established in a learning context (Yackel and Cobb 1996), inferentialism may offer important insights into the relation of social and individual aspects of learning (Schacht and Hußmann 2015; Taylor et al. 2017).

In statistics education, Bakker and Derry (2011) have formulated lessons we can draw from inferentialism. The first is to understand concepts primarily in inferential rather than just representational terms. Put simply, representations are visible and thus apparent, which has also methodological advantages. What inferentialism points to is the invisible inferential terrain that is conditional for understanding representations in the first place. Reasons and inferences tend to go "underground" and inferentialism puts the spotlight on them. The second lesson is that we need to privilege holism over atomism: "one cannot inferentially reason with any concept without drawing on its inferential relations to other concepts" (Bakker and Derry 2011, p. 11). Note that inferentialist ideas go well with many of Vygotsky's ideas, for example:

We must seek the psychological equivalent of the concept not in general representations, ... not even in concrete verbal images that replace the general representations - we must seek it in a system of judgments in which the concept is disclosed. (Vygotsky 1998, p. 55)

These ideas have pedagogical implications. They argue against atomistic teaching approaches in which students learn concepts and graphical representations one by one. Rather, inferentialism suggests that students need to become familiar with systems of judgments, in which the meanings of several concepts become inferentially articulated. In their article, Bakker and Derry (2011) characterise what a shift toward inferentialist approaches to teaching could look like.

New theories are often introduced to repair one-sided views or undesirable consequences of older theories. In our view, dominant current learning theories have their limitations when it comes to understanding the learning of mathematics. For example, Noorloos et al. (2017) argue that constructivism suffers from relativism, an unsatisfactory treatment of the individual-social relationship, and an unclear metaphor of learning as construction. Inferentialism complements Vygotskyan ideas (Derry 2008, 2013) by making visible fine-grained aspects of concept use. The common assumption that any reference to reason entails a form of intellectualism is hard to resist, given that we are so used to think of reason in formalist terms. Despite his emphasis on activity, even 
Vygotsky has been a target of such an unjustified reading (Derry 2013). Reason and inference are the bread and butter of mathematics and hence also of learning and teaching the subject. A richer account of reason will hopefully help to develop the field.

\section{What might inferentialism have to offer in the long run?}

Inferentialism is rooted in a rich philosophical tradition that treats many big philosophical themes such as freedom and the mind-world relationship. Both Brandom and McDowell are praised for their open-mindedness and ability to combine ideas from different traditions (Bernstein 2002; Rorty 1979), in particular analytic philosophy (which can be seen as a basis for most of the cognitive sciences) and continental philosophy (which forms a basis for most of the sociocultural and activity theoretical perspectives, especially through Hegel, Marx, Vygotsky, etc.). Within education, there is a long-standing call for ways to bridge such different traditions (diSessa 2008).

The challenge of putting inferentialist philosophy to work (cf. Cobb 2007) is both daunting and enticing. Crossing the boundaries of disciplines is hard work because key concepts often need reinterpretation. The contributions in this special issue are steps in exploring the value of inferentialism for mathematics education. They are not intended to be a direct application of the work of Brandom or his fellow philosophers; rather, they are the outcome of the authors' appreciation that these ideas offer fertile opportunities to approach questions and issues in new and exciting ways.

The assumption of inferentialism that concepts are inferentially structured could be used to guide the design of learning environments, and the assumption that individuals are responsible for their actions in discursive practices could be used with the help of inferentially structured webs of reasons. Both the mathematical content and an individual's knowledge shown within social practices could be described with the same tools so that designing tasks and reconstructing learning processes are mutually supportive activities (Hußmann and Schacht 2015).

\section{Background of the special issue}

A group of mathematics educators and philosophers convened a series of workshops in their respective universities (Technical University Dortmund in Germany, Utrecht University in the Netherlands, Örebro University in Sweden, University College London in the UK). Workshop papers were presented and discussed, some of which formed the basis of articles in this special issue. At the third meeting at Örebro University, Luis Radford was invited as a discussant; he is the author of the commentary in this special issue.

\section{The articles}

The first article consists of an introduction to inferentialism from the perspective of education, written by a philosopher of education, Jan Derry. She situates inferentialism in its wider philosophical context but also shows it in resonance with educational ideas 
such as Vygotsky's. Her article explains several key concepts and ideas including what it means to privilege the inferential over the representational in any account of meaning.

The second article, by Noorloos, Taylor, Bakker, and Derry-three philosophers and one mathematics educator, argues that inferentialism can overcome problems that plague constructivism including the variant that is popular in mathematics education, socioconstructivism. Their argument is that inferentialism provides the resources with which to develop an alternative learning theory.

Mackrell and Pratt, in the third article, criticise constructivism for not accounting well for affect. As an alternative basis for Papert's constructionism, they propose a framework that is inspired by philosophical ideas concerning the space of reasons - rather than cold reasons; they argue for a conception of reasons that fully accounts for the affective dimension of thought. While their framework is not directly inspired by Brandom's inferentialism, it may still be considered to lie within the field of thought that attends to the inferential aspect of activity. Mackrell and Pratt are influenced by philosophers such as John McDowell and David Bakhurst whose ideas may be connected with Brandom's and the Russian psychologists in the Vygotskyan tradition (Ilyenkov, Leontiev).

Following these theoretical articles, two empirical ones engage with the ideas. The first, by Schindler, Hußmann, Nilsson, and Bakker, is on negative numbers. Inferentialist ideas are used to analyse how students infer from experiences in and out of school when they judge order relations between negative numbers. In particular, the article elaborates on epistemological considerations derived from inferentialism. The results of the empirical study illustrate that although students' reasoning may appear illogical or inconsistent at first sight, it may follow a certain logic that students infer from prior experiences.

The second empirical article, by Bakker, Ben-Zvi, and Makar, presents a case study of an intern who makes statistical inferences in a hospital laboratory. The authors use inferentialist concepts to structure their study of how reasons and actions are coordinated in the process of making statistical inferences. Both empirical studies illustrate a reworking of the original inferentialist concepts in order to analyse empirical data.

Finally, as a critical friend, Radford provides a thought-provoking commentary by placing inferentialism in a wider theoretical landscape and comparing it with theories that are well known within mathematics education research. His provocative and stimulating contribution demonstrates that discussion of inferentialism can revive thorny and long-standing debates on fundamental questions in mathematics education from questions concerning the nature of mathematics to questions concerning the nature of human beings.

We hope that these contributions will be read as initial steps on a long but interesting and fruitful journey.

\section{References}

Bakker, A. \& Derry, J. (2011). Lessons from inferentialism for statistics education. Mathematical Thinking and Learning, 13, 5-26.

Bakker, A., Ben-Zvi, D., \& Makar, K. (2017). An inferentialist perspective on the coordination of actions and reasons involved in making a statistical inference. Mathematics Education Research Journal. https://doi. org/10.1007/s13394-016-0187-x. 
Bakker, A., Kent, P., Derry, J., Noss, R., \& Hoyles, C. (2008). Statistical inference at work: statistical process control as an example. Statistics Education Research Journal, 7(2), 130-145.

Bernstein, R. J. (2002). McDowell's domesticated Hegelianism. In N. H. Smith (Ed.), Reading McDowell on mind and world. Abingdon: Routledge.

Brandom, R. B. (1994). Making it explicit. Reasoning, representing, and discursive commitment. Cambridge: Harvard University Press.

Brandom, R. B. (2000). Articulating reasons: an introduction to inferentialism. Cambridge, MA: Harvard University Press.

Brandom, R. B. (2008). Between saying and doing: towards an analytic pragmatism. Oxford: Oxford University Press.

Brandom, R. (2009). Reason in philosophy: animating ideas. Cambridge: Harvard University Press.

Cobb, P. (2007). Putting philosophy to work: coping with multiple theoretical perspectives. In F. Lester (Ed.), Second handbook of research on mathematics teaching and learning (pp. 3-38). Greenwich: Information Age.

Cobb, P., Yackel, E., \& Wood, T. (1992). A constructivist alternative to the representational view of mind in mathematics education. Journal for Research in Mathematics Education, 23(1), 2-33.

Derry, J. (2008). Abstract rationality in education: from Vygotsky to Brandom. Studies in Philosophy and Education, 27(1), 49-62.

Derry, J. (2013). Vygotsky: philosophy and education. Oxford: Wiley Blackwell.

diSessa, A. (2008). A note from the editor. Cognition and Instruction, 26, 427-429.

Erickson, P., Klein, J. L., Daston, L., Lemov, R., Sturm, T., \& Gordin, M. D. (2013). How reason almost lost its mind: the strange career of Cold War rationality. Chicago: University of Chicago Press.

Freudenthal, H. (1973). Mathematics as an educational task. Dordrecht: Reidel.

Hußmann, S., \& Schacht, F. (2015). Fachdidaktische Entwicklungsforschung in inferentieller Perspektive am Beispiel von variable und term (design research in an inferential perspective, illustrated by variable and term). Journal für Mathematik-Didaktik, 36(1), 105-134.

Lakatos, I. (1976). Proofs and refutations: the logic of mathematical discovery. Cambridge: Cambridge University Press.

Mackrell, K., \& Pratt, D. (2017). Constructionism and the space of reasons. Mathematics Education Research Journal. https://doi.org/10.1007/s13394-017-0194-6.

McDowell, J. (1994/1996). Mind and world. Cambridge, MA: Harvard University Press.

Noorloos, R., Taylor, S., Bakker, A., \& Derry, J. (2017). Inferentialism as an alternative to socioconstructivism in mathematics education. Mathematics Education Research Journal. https://doi.org/10.1007/s13394017-0189-3.

Rorty, R. (1979). Philosophy and the mirror of nature. Princeton: Princeton University Press.

Schacht, F., \& Hußmann, S. (2015). Between the social and the individual: reconfiguring a familiar relation. Philosophy of Mathematics Education Journal, (29), 1-26. http://socialsciences.exeter.ac. uk/education/research/centres/stem/publications/pmej/pome29/index.html.

Schear, J. K. (Ed.). (2013). Mind, reason, and being-in-the-world: the McDowell-Dreyfus debate. Routledge: London.

Schindler, M., \& Hußmann, S. (2013). About students' individual concepts of negative integers - in terms of the order relation. In B. Ubuz, C. Hacer, \& M. A. Mariotti (Hrsg.), Proceedings of the Eighth Congress of the European Society for Research in Mathematics Education (CERME 8) (pp. 373-382). http://www. mathematik.uni-dortmund.de/ erme/doc/CERME8/CERME8_2013_Proceedings.pdf.

Smith, N. (Ed.). (2002). Reading McDowell: on mind and world. Abingdon: Routledge.

Taylor, S. D., Noorloos, R., \& Bakker, A. (2017). Mastering as an inferentialist alternative to the acquisition and participation metaphors for learning. Journal of Philosophy of Education, (in press).

Tversky, A., \& Kahneman, D. (1981). The framing of decisions and the psychology of choice. Science, 211, $453-458$.

Vygotsky, L. S. (1998). The collected works of L.S. Vygotsky, volume 5, child psychology R.W. Reiber (Ed.). New York, NY: Plenum.

Weiss, B., \& Wanderer, J. (Eds.). (2010). Reading Brandom: on making it explicit. New York: Routledge.

Yackel, E., \& Cobb, P. (1996). Sociomathematical norms, argumentation, and autonomy in mathematics. Journal for Research in Mathematics Education, 27(4), 458-477.

Williams, B. (1981). Persons, character, and morality. In: James Rachels (ed.), Moral luck. Cambridge, UK: Cambridge University Press. 